\title{
Samtal:
}

\section{Om museifestivalen i Stavanger i maj 1998}

Med anledning av Åse Enerstvedts kritik av juryns arbete vid museifestivalen i Stavanger i fjol med temat Vän eller Fiende?, vill undertecknad framföra följande:

För det första. Åse Enerstvedt har både rätt och fel $i$ att en festival inte är rätta platsen för en jury att kritisera utställningsidéerna. $\AA$ andra sidan säger hon själv på föregående sida, att den som deltar med utställningsidéer må vara förberedd på både god och dålig kritik, «en erfaring som museumsfolk ikke er vant til». Just det. Och det var precis vad som skedde i Stavanger.

Det var Erik Hofréns idé, om jag minns rätt, och vi tyckte alla att den var god. Tanken var att varje förslag skulle tas på allvar, idéerna och förslagen skulle studeras och utvärderas grundligt. Var och en skulle få ut något, även om de inte fick pris. När får, precis som Enerstvedt säger, museiplanerarna tillfälle att få sina idéer vägda och mätta på detta sätt? Att våra omdömen sedan upplevdes, och möjligen utföll, som alltför mycket negativ kritik, är en annan sak, och mycket beklagligt. Inte minst som jag upplevde det som ett hedrande uppdrag.

Men vi såg, och ser, en museifestival också uttryckligen som ett tillfälle att väcka diskussion om museernas och museiutställningars idé, uppgift och tillstånd!

För det andra. Enerstvedt har förstås, liksom publiken, rätt att säga vilket utställningsförslag hon tyckte var bäst. Det har också juryn. Det vinnande förslaget var på sätt och vis, såsom Enerstvedt säger, konventionellt, men det var också nästan alla andra! Utom ett par, nämligen förslagen från Tromsö och Stockholm, av vilka det sistnämnda vann pris för teknisk lösning.

Det goda med det vinnande förslaget bland utställningsidéerna var att museiverksamheten här på ett förtjänstfullt sätt integrerade museet i samhället. Museet spelade rollen av ett levande kultur- hus, som aktivt följde med ortens invånares livssituation och behov, och tog in dem själva, och framför allt invandrarna, i utställningsbygget.

Stavangers arkeologiska museums permanenta del var ett liknande positivt exempel på att tillmötesgå en modern publik och dess behov och krav.

Många av festivalidéerna kom emellertid något von oben.....ta zigenarutställningen. Där hade ju inte, så vitt jag förstod, zigenarna själva varit med om planeringsprocessen. Jag undrar vad de skulle ha sagt om man hade frågat dem: vill ni bli utställda? Lite sådär som att på 1800-talet ställa ut «negerkultur"...?

För det tredje. Enerstvedt har helt fel i att Tromsö-gruppens förslag skulle ha varit värt ett pris. De missade nämligen hela poängen på vägen mellan idé och utställningsförslag. Utgångspunkten var att visa hur negativt det är att använda mycket datateknologi i museerna. Medan själva utförandet och dess verkan var absolut positiv! Deras utställningsförslag var vackert och tilltalande på allt sätt, och man klev ut i den fasta övertygelsen att om detta är intrycket av att använda datateknologi på museerna, så fritt fram bara! Effekten blev således motsatt intentionen.

Enerstvedt har också fel i sitt påstående att denna utställningsidé, liksom Stockholmsungdomarnas, var abstrakt. Idén, datorer i museerna, var ingalunda abstrakt. Det var utförandet som var abstrakt här.

För det fjärde. Apropå det vinnande tekniska förslaget - utställningsfestivalen har ju programmatiskt tagit till sin uppgift att vaska fram nytänkande och nya fräscha idéer för museiutställningar. Priset gavs uttryckligen för ett sådant nytänkande, inte för något annat. Att Stockholmsungdomarnas abstrakta idé för att kunna förverkligas ännu behövde mogna en del, är en annan sak.

Beträffande förslagen till tekniska lösningar 
186 beklagar jag efteråt djupt att Jan Polasek från Stockholm blev utan hedersomnämnande; hans vitrinlösning var både vacker och genial, och mycket användbar i nästan vilka utställningssammanhang som helst!

För det femte och till sist: juryn var väl medveten om att framför allt publiken trodde att Stavanger museums «vargutställning» skulle vinna första pris. Motiveringen till att den blev utan har vi levererat skriftligt.

Utgångspunkten, vargen och människan, som väl gick tillbaka på den livsfilosofiska devisen Homo homini lupus (människan är människans varg) var alldeles utmärkt, men själva utställningsidén sedan mindre intressant. Enerstvedt beklagade att juryn hade behäftat utställningsidén med stämpeln «barnslig» eller «alltför mycket gjord för barn», som väl undslapp oss. Hon menar att barnen och deras behov tvärtom bör lyftas fram, eftersom de är en så viktig målgrupp. Det kan hon ha rätt $i$, men nu närmar vi oss den stora fråga, som tarvar en helt egen och djupare diskussion.

Min åsikt är att museerna idag stirrar sig smått blinda på sin pedagogiska uppgift. De skall vara kunskapsbanker, komplement till skolorna, servera kunskap i smakliga förpackningar. Visst. Nivån sänks då ofta ner till barnanivå. Men det må vara en vuxen förlåtet om han/hon upplever en utställning som barnslig. Ibland har man rentav en känsla av att de vuxna glöms bort i utställningarna. Allt det där med totalupplevelse, kulisser och skådespeleri på museerna börjar ju dessutom vara «out». Det var roligt på 1980-talet, med Vikingacentret i York och andra i spetsen. Utställningarna började överallt alltmer likna film. Besökaren steg så in i filmen, och skulle där uppleva allt det hans förfäder upplevat, osv. Men vem har sagt att vi alla (vuxna) vill sätta oss i ett litet upplevelsetåg på räls som för oss igenom utställningen, alternativt slussas in $\mathrm{i}$ en Oneway-gånglabyrint utan möjlighet att gå tillbaka, eller knappt ens att stanna upp för någon längre stund, eftersom folk pressar på bakifrån...
Var finns möjligheterna till kontemplation och begrundan, att inte tala om meditation i Tiden och Rummet, som museerna också borde erbjuda? Att orientera sig i det kosmos som är vårt, kräver inte nödvändigtvis en massa teaterspel och clownkonster!? Befinner sig inte museerna i kris?

Dessutom: den under senare år ökande tendensen att börja tillämpa de ekonomiska marknadskrafternas lagar på museerna, dvs. att göra dem till affärsföretag, kan innebära dödsstöten för dem på lång sikt.

Kerstin Smeds, jurymedlem

\section{Kerstin Smeds är docent $i$ historia vid Helsingfors universitet, och museiforskare med identitet och utställningar som specialitet}

Per Råberg (red.): The Life Region. The Social and Cultural Ecology of Sustainable Development. Acta Universitatis Umensis 131. Umeå Universitet 1996. ISBN 91-7174-835-0

Flere års prosjektarbeid ligger bak boka The Life Region som Per Råberg har redigert. Råberg har egentlig gjort langt mer enn å redigere, - han har skrevet størstedelen av boka, og han har også gjennom sin virksomhet i Kollegiet för humanistiska framtidsstudier ved Universitetet i Umeå vært pådriver og organisator for de tre konferansene i Västernorrland, der mange av bidragene i boka ble presentert (Härnösand april 1992, Örnsköldsvik, juni 1992 og juni 1993).

Den økologiske livsregion er titelen på den modell Umeå-gruppen har orientert seg ut fra, - her beskrevet og utdypet som en sosio-økologisk tilnærmingsmåte. De ulike bidragene i boka kommer fra deltakere i Umeå-gruppens internasjonale nettverk, - forskere og debattanter som tilhører en kritisk humanistisk tradisjon.

Begrepet den okologiske livsregionen er knyttet til en forståelse av hva som utgjør det enkelte individs 